\title{
KISS1 wt Allele
}

National Cancer Institute

\section{Source}

National Cancer Institute. KISS1 wt Allele. NCI Thesaurus. Code C54288.

Human KISS1 wild-type allele is located in the vicinity of $1 \mathrm{q} 32$ and is approximately $6 \mathrm{~kb}$ in length. This allele, which encodes metastasis-suppressor KiSS-1 protein, plays a role in metastasis suppression. 